[CONTRIBUTIONS FROM THE HAVEMEYER LABORATORIES OF COLUMBIA UNIVERSITY, No. 129.]

\title{
SEASONAL VARIATIONS IN THE COMPOSITION OF COWS' MILK.
}

BY H. C. SHERMAN.

Received September 24 , Igot.

IT is well-known that cows' milk tends to show higher percentages both of fat and of solids-not-fat in winter than in summer, and the extent of these variations as shown by the average composition of many thousands of samples received by the Aylesbury Dairy Company of London has been deternined by Richmond for several years past. ${ }^{1}$ Comparatively few data are available to show whether the seasonal variations found in England apply likewise to American conditions, or to determine to which constituent the variation in percentage of solids-not-fat is chiefly due. ${ }^{2}$

The average results of a series of analyses covering five years and bearing upon these points is shown below, Table I. The figures given for each month are obtained by averaging the results of analyses of monthly samples of the mixed milk of the herd, taken at the afternoon milking of one day each month for five successive years. The results as a whole represent complete analyses of 6o samples, each an accurate composite of the entire milk of a dairy herd in Westchester County, New York, averaging about 600 cows. About one-third of the cows were registered Jerseys and most of the remainder were Jersey grades. Before and during the time covered by this investigation the cows were selected and the herd managed with a view to the production of milk rich in fat. The system of feeding was liberal throughout. During the first two years, hay, grain and pasture were used exclusively; later, roots and ensilage were sometimes added to the ration. The herd was warmly housed in winter and was so managed that the proportion of fresh cows did not differ greatly at different seasons of the year. It is believed, therefore, that the differences shown by the average results for each month may

${ }^{1}$ Dairy Chemistry (London, I899) and yearly papers in The Analyst.

${ }^{2} \mathrm{~A}$ series of analyses covering two years and bearing upon the same question has been published in a previous paper from this laboratory. This Journal, 25, i 32 (1903). 
properly be attributed to seasonal variations in the composition of the milk.

The results of the analyses covering September, I900, to August, 1905, inclusive, are shown in Table I.

TABLE I.

Average Composition of Afternoon Milk, September, I900, to August, I905.

\begin{tabular}{|c|c|c|c|c|c|c|c|c|}
\hline \multirow{2}{*}{\multicolumn{3}{|c|}{ January, average... }} & \multirow{2}{*}{$\begin{array}{l}\text { Fat. } \\
5.57\end{array}$} & \multirow{2}{*}{$\begin{array}{c}\text { Solids- } \\
\text { not-fat. } \\
9.37\end{array}$} & \multirow{2}{*}{$\begin{array}{c}\text { Protein. } \\
3.80\end{array}$} & \multirow[t]{2}{*}{$\begin{array}{l}\text { Milk- } \\
\text { sugar. } \\
4.82\end{array}$} & \multirow{2}{*}{$\begin{array}{l}\text { Ash. } \\
0.76\end{array}$} & \multirow{2}{*}{$\begin{array}{l}\text { Tota1 } \\
\text { solids } \\
\text { I } 4.94\end{array}$} \\
\hline & & & & & & & & \\
\hline February, & $" 6$ & n........... & $5 \cdot 5^{2}$ & $9 \cdot 39$ & $3 \cdot 77$ & 4.86 & 0.76 & I $4.9 \mathrm{I}$ \\
\hline March, & $" 6$ & ............. & 5.46 & 9.27 & 3.66 & 4.86 & 0.75 & I 4.73 \\
\hline April, & " & n.......... & 5.42 & 9.18 & 3.60 & 4.84 & 0.74 & $\mathrm{I} 4.60$ \\
\hline May, & “ & $\ldots \ldots \ldots \ldots$ & $5 \cdot 4^{\circ}$ & 9.17 & 3.57 & 4.86 & 0.74 & 14.57 \\
\hline June, & " & & 5.53 & 9.11 & 3.57 & 4.79 & 0.75 & I 4.64 \\
\hline July, & “ & .............. & 5.24 & 8.96 & 3.49 & $4 \cdot 73$ & 0.74 & $\mathrm{~J} 4.20$ \\
\hline August, & “ & ........... & 5.26 & 9.02 & 3.53 & 4.74 & 0.74 & I 4.28 \\
\hline September, & $"$ & $\ldots \ldots \ldots \ldots$ & 5.33 & 9. I 5 & 3.62 & 4.79 & 0.74 & I 4.48 \\
\hline October, & " & $\ldots \ldots \ldots \ldots$ & $5 \cdot 36$ & 9.26 & $3 \cdot 70$ & $4.8 \mathrm{r}$ & 0.75 & 14.62 \\
\hline November, & $"$ & ............ & $5 \cdot 3^{8}$ & $9 \cdot 35$ & 3.80 & $4.8 \mathrm{r}$ & 0.75 & I 4.73 \\
\hline December, & ‘ & n.......... & 5.52 & 9.43 & 3.85 & 4.82 & 0.76 & I 4.95 \\
\hline reneral & $"$ & ............ & 5.42 & 9.22 & 3.66 & $4.8 \mathrm{I}$ & 0.75 & I 4.64 \\
\hline
\end{tabular}

The average results for the five-year period indicate that the percentages of fat, protein and milk-sugar (and of total solids and solids-not-fat) all reach a minimum in July, while the maximum percentages are reached in December, January or February.

The average results for the fat and solids-not-fat as given by Richmond for the afternoon milk of the same five years ${ }^{1}$ have been calculated by months with the results shown in Table II.

Comparison of Richmond's results with those of the writer shows that the minimum percentages are reached at about the same time, usually in July. In the following months the solidsnot-fat rise steadily in both cases and are highest in December, January and February, while the percentage of fat rises more rapidly in the English than in the American samples, being highest in October and November in the former, and in January in the latter. The highest average percentages of total solids are found in October, November and December by the English, and in December, January and February by the American analyses.

1 The mean monthly averages found by Richmond for a period of sixteen years ending 1899 are given in his Dairy Chemistry, p. I27, and show variations similar to those in Table II, except that the maximum for solidsnot-fat occurs somewhat earlier in the older series of analyses. 
TABLE II.

Average Results of Richmond's Analyses, September, I900, to August, I905, Inclusive.

Fat.

\begin{tabular}{|c|c|c|}
\hline February, & " & ....... \\
\hline March, & ") & $\ldots \ldots \ldots \ldots \ldots$ \\
\hline April, & " & ............... \\
\hline May, & "4 & \\
\hline June, & “ & .......... \\
\hline July, & " & $\cdots$ \\
\hline August, & “ & \\
\hline September, & “ & n............. \\
\hline October, & ‘ & ................ \\
\hline November, & “ & n.............. \\
\hline December, & " & ................ \\
\hline & . & \\
\hline
\end{tabular}

$\begin{array}{cc}\text { Solids-not-fat. } & \text { Total solids. } \\ 9.02 & \mathrm{I} 3.01 \\ 9.00 & \mathrm{I} 2.92 \\ 8.98 & \mathrm{I} 2.87 \\ 8.93 & \mathrm{I} 2.79 \\ 8.97 & 12.82 \\ 8.92 & \mathrm{I} 2.7 \mathrm{I} \\ 8.77 & \mathrm{I} 2.59 \\ 8.78 & \mathrm{I} 2.77 \\ 8.88 & \mathrm{I} 2.92 \\ 8.94 & \mathrm{I} 3.08 \\ 8.96 & \mathrm{I} 3.10 \\ 8.98 & \mathrm{I} 3.08 \\ \overline{8.93} & \mathrm{I} 2.89\end{array}$

In order to bring the results into form convenient for comparison the average figure for each month for fat, solids-not-fat, and total solids is calculated as percentage of the general average and these percentages for Richmond's analyses and those of the writer are given in Table III.

TABIE III.

Monthly Averages in Percentages of General Averages : Fat, Solids-not-fat, and Total Solids.

\begin{tabular}{|c|c|c|c|c|c|c|}
\hline \multirow{2}{*}{\multicolumn{2}{|c|}{$\begin{array}{c}\text { Richmond } \\
\text { London. } \\
\text { January ...... I00.8 }\end{array}$}} & \multirow{2}{*}{$\begin{array}{l}\text { at. } \\
\text { 'Sherman, } \\
\text { New York. } \\
\text { IO2.8 }\end{array}$} & \multicolumn{2}{|c|}{$\begin{array}{l}\text { Solids-not-fat. } \\
\text { Richmond, Sherman, } \\
\text { London. New York. }\end{array}$} & \multicolumn{2}{|c|}{$\begin{array}{l}\text { Total solids. } \\
\text { Richnond, Sherman, } \\
\text { London. New York. }\end{array}$} \\
\hline & & & IOT.O & IOI. 6 & 100.9 & 102.0 \\
\hline February ... & 99.0 & IOI. 8 & 100.8 & 101.8 & $I \infty 0.2$ & 101.8 \\
\hline March ......... & 98.2 & 100.7 & 100.6 & 300.5 & 99.8 & 100.6 \\
\hline April ........ & 97.5 & 100.0 & 100.0 & 99.6 & 99.2 & 99.7 \\
\hline May ............ & 97.2 & 99.6 & 100.4 & 99.5 & 99.5 & 99.5 \\
\hline June ........... & . $\quad 95.7$ & 102,0 & 99.9 & 98.8 & 98.6 & I00.O \\
\hline July........... & . 96.5 & 96.7 & 98.2 & 97.2 & 97.7 & 97.0 \\
\hline August....... & .. 100.8 & 97.0 & 98.3 & 97.8 & 99. I & 97.5 \\
\hline September.. & .. 102.0 & 98.3 & 99.4 & 99.2 & 100.2 & 98.9 \\
\hline October ..... & 104.5 & 98.9 & 100.1 & 100.4 & 101.5 & 99.9 \\
\hline November. & . 104.5 & 99.3 & 100.3 & IOI.4 & 101.6 & 100.6 \\
\hline December.. & .. 103.5 & ror.8 & 100.5 & 102.3 & IOI.5 & IO2.I \\
\hline
\end{tabular}

The results of a similar calculation of the percentage variation of the monthly averages for protein, milk-sugar, and ash in the samples of New York milk are shown in Table IV. 
TABLE IV.

Monthly Averages in Percentage of General Averages: Protein, Milk-sugar and Ash.

\begin{tabular}{|c|c|c|c|}
\hline January ....................... & $\begin{array}{c}\text { Protein. } \\
\text {. IO3.8 }\end{array}$ & $\begin{array}{c}\text { Milk-sugar. } \\
100.2\end{array}$ & $\begin{array}{l}\text { Ash. } \\
\text { IOI } 3\end{array}$ \\
\hline February......................... & . 103.0 & IOI.O & IOI.3 \\
\hline March....................... & .100 .0 & IOI.O & 100.0 \\
\hline April ........................ & . 98.1 & 100.6 & 98.7 \\
\hline May...$\ldots \ldots \ldots \ldots \ldots \ldots \ldots \ldots \ldots \ldots$ & $97 \cdot 3$ & IOI.O & 98.7 \\
\hline June $\ldots \ldots \ldots \ldots \ldots \ldots \ldots \ldots$ & 97.3 & 99.6 & 100.0 \\
\hline July $\ldots \ldots \ldots \ldots \ldots \ldots \ldots \ldots \ldots$ & 95.4 & 98.3 & $9^{8.7}$ \\
\hline 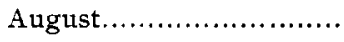 & - 96.4 & 98.5 & 98.7 \\
\hline September.................. & . 99.5 & 99.6 & 98.7 \\
\hline October ...................... & .100 .5 & 100.0 & 100.0 \\
\hline November ................... & .103 .8 & 100.0 & 100.0 \\
\hline December ..................... & . 105.2 & 100.2 & Ior.3 \\
\hline
\end{tabular}

The variations of individual constituents in the New York samples are compared in Table $\mathrm{V}$ both for single months and for six-month periods.

TABLE V.

Comparison of Seasonal Variations: Fat, Protein, Sugar and Ash.

Fat.

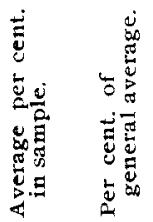

Max. monthly average... 5.57

Min. monthly average..

Difference

$$
\frac{5.24}{0.33}
$$

I02.8

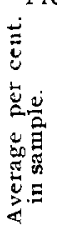
Protein.

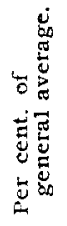

Milk-sugar.

Ash.
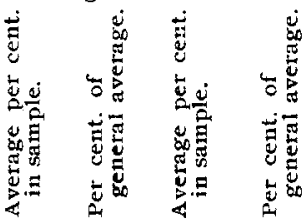

105.2

4.86

IOI.O

0.76 IOI. 3

$96.7 \quad 3.49$

$95.4 \quad 4.73$

$\begin{array}{lll}98.3 & 0.74 & 98.7\end{array}$

$\begin{array}{lll}9.8 & 0.13\end{array}$

$\begin{array}{lll}2.7 & 0.02 & 2.6\end{array}$

$\begin{array}{llllllll}\text { Aver. October to March.. } 5.47 & \text { I0o.9 } & 3.76 & \text { I02.6 } & 4.83 & \text { 100.4 } & 0.755 & \text { 100.7 }\end{array}$

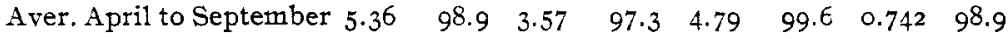

Difference

$$
\text { O.II } \quad \frac{5}{2.0} \frac{1.19}{0.19}
$$

$\begin{array}{llll}0.8 & 0.013 & -1.8\end{array}$

CONCLUSIONS.

Monthly analyses of the mixed milk of about 600 cows extending over a period of five years show seasonal variations in percentages of fat and solids-not-fat similar in general to those found by Richmond but differing in that the fat varied less in proportion to the amount present and reached a maximum somewhat later in the winter, while the solids-not-fat varied more than in Richmond's samples for the same period, and reached a maximum about a month earlier. 
The seasonal variation was more regular, and was greater both in actual figures and in proportion to the amount present, in the case of protein than in the case of fat.

From October to March the average percentages of all the constituents were higher than from April to September. The difference in milk-sugar is much less, both relatively and absolutely, than the differences in protein and fat. The seasonal variation in percentage of ash is very slight, although in proportion to the amount present it is no smaller than the variation in milk-sugar.

The seasonal variations in solids-not-fat are due chiefly to changes in the percentage of protein.

\section{THE DETERMINATION OF ROSIN IN VARNISHES.}

By Augtstus H. Gill.

Received October I, Igo6.

THE presence of rosin in a varnish decreases its resisting power to atmospheric agencies, its power of adhesion to surfaces, and its hardness; furthermore, it means the substitution of the valuable copal or kauri by the cheap rosin or "South Carolina Zanzibar."

The procedure followed consists in the elimination of the turpentine by distillation with steam, of the oil by Twitchell's process, thus obtaining the pure gum resins. These were examined at first by the Hübl method, Table I, then by McIlhiney's bromine method, Table II, and finally and most satisfactorily, the saponification, free acid and ester values, Table V, were determined.

Sixty grams of the well-mixed varnish are weighed into a 500 cc. round-bottomed flask, this connected with a condenser and a two-quart can which furnishes steam; the varnish is warmed just above $100^{\circ}$ by a small flame and kept at this point to prevent the condensation of the steam used for distillation. The distillation is continued until about $500 \mathrm{cc}$. of water have passed over, or until there is but a faint odor of turpentine in the last portions of the distillate. It was noticed with a pure rosin varnish that only a small portion of the gum sticks to the flask, while with pure copal varnish the gum coats the inside of the flask almost completely.

The solvent may be separated from the water, dried by anhy- 